\title{
Sexual Dimorphism Determination by Piriform Aperture Morphometric Analysis in Brazilian Human Skulls
}

\author{
Determinación de Dimorfismo Sexual Mediante Análisis Morfométrico \\ de la Apertura Piriforme en Cráneos Humanos Brasileños
}

"Mario Cantín López; ",**Iván Claudio Suazo Galdames; " Daniela Alejandra Zavando Matamala \& ** Ricardo Luiz Smith

CANTÍN, L. M.; SUAZO, G. I. C; ZAVANDO, M. D. A \& SMITH, R. L. Sexual dimorphism determination by piriform aperture morphometric analysis in Brazilian human skulls. Int. J. Morphol., 27(2):327-331, 2009.

SUMMARY: The sex determination of human skeletons is important in forensic and anthropological research. It can be carried out through qualitative or quantitative analysis of morphological parameters of dimorphism. The shape of the piriform aperture is one of the classic indicators of sexual dimorphism since it describes differences between males and females according to strong populationspecific behavior. The purpose of this study was to analyze the presence of sexual dimorphism in the size of the piriform aperture and its relationship with individual skin color. We used 90 human skulls from the Collection of the Federal Universidad de Sao Paulo (UNIFESP), with registered data on sex, age and skin color (classified as white, black and brown). The dimensions studied were: height, upper width and lower width of piriform aperture. All dimensions were greater in males than females, however, only the piriform aperture height was found to be significant with $\mathrm{p}<0.01$. By analyzing differences and grouping them according skin color, the piriform aperture height was found to be significantly higher $(\mathrm{p}<0.05)$ in white, black and brown males. In the group of black individuals skulls, we found significant differences in the upper width $(\mathrm{p}<0.05)$. The main differences, related to the piriform aperture height and the low influence of skin color in the presence of sexual dimorphism in the piriform aperture size, are in contrast with what has been reported in the literature and justify the revision of the classic indicators used for diagnosis of sex in specific populations.

KEY WORDS: Sexual dimorphism; Piriform aperture; Skulls.

\section{INTRODUCTION}

The process by which we recognize males and females within a population is based on the quick and systematic assessment of all dimorphic features, more highly accurate methods for diagnosis according to sex (Pascalis $e t$ al., 2002). The pelvis and the skull bone pieces are the best expressions of differences attributable to sex (Correia et al., 2005).

The skull has a high resistance to adverse environmental conditions over time, resulting in the greater stability of the dimorphic features as compared to other skeletal bone pieces. The shape of the piriform aperture is one of the classic indicators of morphological sexual dimorphism (Krogman \& Iscan, 1986). In women the width predominates the height and margins are rounded, in contrast to the male where the height dominates the width.
Rogers (2005) and Williams \& Rogers (2006) analyzed the diagnostic value of different morphological indicators of sexual dimorphism. They found that the shape of the piriform aperture was a good indicator for the diagnosis of sex. Suazo et al. (2008a; 2008b; 2008c) reported a high number of false positives when assessing the performance of different indicators as a diagnostic test of dimorphism. Moreover, morphometric studies in piriform aperture in German and Korean populations showed the presence of sexual dimorphism in some of its dimensions (Hommerich \& Riegel, 2002; Hwang et al., 2005; Lee et al., 2008). Race difference should be included in assessing the dimorphic characteristics of the piriform aperture. Several authors have reported a high variance in the size of piriform aperture in studies among groups of subjects of different skin colors. The sexual dimorphism in the size of the piriform

\footnotetext{
* Departamento de Anatomía Normal, Universidad de Talca, Chile.

** Departamento de Morfología y Genética. Universidade Federal de São Paulo, Brazil.
} 
aperture can be influenced by racial issues, especially in populations where there are miscegenation (Hoffman et al., 1991; Ofodile, 1994).

Considering the high heterogeneity of the Brazilian population, Brazilian skulls were chosen as subjects for this study. The purpose of this study is to determine the presence of dimorphism in the piriform aperture in a sample of skulls from Brazilian individuals classified according skin color in white, black and brown from the Collection of Universidade Federal de São Paulo (UNIFESP), Brazil.

\section{MATERIAL AND METHOD}

Non-probability sampling of 90 human skulls were selected from the collection of dried skulls of the Universidade Federal de Sao Paulo (UNIFESP). The criteria for inclusion in the study were the availability of a complete record of sex, age at death, skin color data. The skulls belonged to Brazilians individuals older than 18 years, and did not bear evidence of trauma, asymmetries or craniofacial abnormalities.

Three groups were formed:

Group A: 30 skulls of individuals with white skin color, 15 male and 15 female.

Group B: 30 skulls of individuals with black skin color, 15 males and 15 females.

Group C: 30 skulls of individuals with brown skin color, 15 males and 15 females.

Demographic characteristics of the three groups that constitute the sample are shown in Table I. Using a digital caliper $(0.01 \mathrm{~mm})$, the dimensions of the piriform aperture were identified accordingly:

a. Upper width: The upper width is measured from the left and right nasomaxillary suture at the lower limit of left and right nasal bones with the maxillary bone, according to the method described by Lang \& Baumeister (1982) (Fig. 1).

b. Lower width: The lower width is described as the area of the piriform aperture with greater separation between the frontal process of the maxillary bone on each side of the midsagital planum, which is the widest area of the piriform aperture (Hwang et al.; Hommerich \& Riegel) (Fig. 1).

c. Height of the piriform aperture: The height corresponds to the distance between the Nasion (N) and Nasospinal (Ns), which is the lowest point of the lower edge of the piriform aperture in the base of the anterior nasal spine (Fig. 1).
The skulls were arranged randomly and measurements were made by one observer, blinded in relation to the registration of sex, age and skin color, throughout the investigation. Statistical analysis was done using the statistical software package SPSS 15.0. The significance of differences in average values in males and females, viewed as a whole and divided into groups according to color, was established by t-test for independent samples with $\mathrm{p}<0.05$.

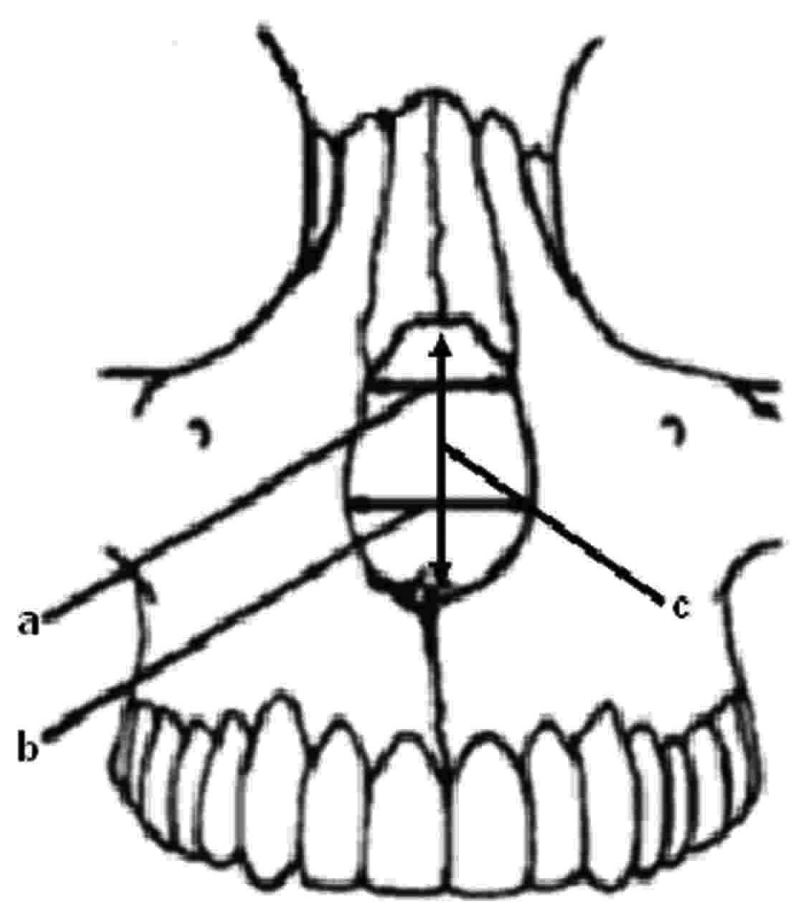

Fig. 1. Schematic illustration of the piriform aperture measurements. a) upper width, b) lower width and c) height.

\section{RESULTS}

Analyzing the height and upper and lower widths of the opening piriform by sex, all dimensions were greater in male skulls than female skulls, but only the height of the piriform aperture yielded a statistical significance $\mathrm{p}<0.01$ (Table I). In a separate analysis according to color, the height of the piriform aperture was significantly higher $(\mathrm{p}<0.05)$ in whites, blacks and browns male skulls. In the skulls belonging to the black group, significant differences were found in the lower width of piriform aperture $(\mathrm{p}<0.05)$. In the white group, all measurements were higher for males, except for the upper width of the piriform aperture that was higher in females; however, these differences were not statistically significant (Table II). 
CANTíN, L. M.; SUAZO, G. I. C; ZAVANDO, M. D. A \& SMITH, R. L. Sexual dimorphism determination by piriform aperture morphometric analysis in Brazilian human skulls. Int. J. Morphol., 27(2):327-331, 2009.

Table I. Descriptive statistics of the measurements made at the piriform aperture in skulls by sex.

\begin{tabular}{lcccccccc}
\hline & Sex & n & Min & Max & Mean & DS & Typical error & Sig. (bilateral) \\
\hline Height & Male & 45 & 46.11 & 57.58 & 50.8269 & 2.82732 & .42147 & $.000^{*}$ \\
\multirow{4}{*}{ Upper width } & Female & 45 & 38.71 & 53.02 & 47.5349 & 3.29823 & .49167 &. \\
& Male & 45 & 13.29 & 22.21 & 17.6078 & 2.25430 & .33605 & .399 \\
& Female & 45 & 12.75 & 22.53 & 17.2093 & 2.20130 & .32815 & .71558 \\
& Male & 45 & 21.20 & 34.04 & 26.8731 & 4.80023 & .052 \\
\hline
\end{tabular}

Table II. Statistical group skulls as skin color: White, Black and Brown, and sex. * Piriform aperture.

\begin{tabular}{|c|c|c|c|c|c|c|c|}
\hline Skin color & & Sex & $\mathrm{n}$ & Mean & DS & Typical error & Sig. (bilateral) \\
\hline \multirow[t]{6}{*}{ White } & \multirow[t]{2}{*}{ Height $^{*}$} & Male & 15 & 51.29 & 2.181 & .563 & .005 \\
\hline & & Female & 15 & 48.03 & 3.476 & .897 & .005 \\
\hline & \multirow[t]{2}{*}{ Upper width* } & Male & 15 & 16.75 & 1.947 & .502 & .436 \\
\hline & & Female & 15 & 17.32 & 1.997 & .515 & .436 \\
\hline & \multirow[t]{2}{*}{ Lower width" } & Male & 15 & 26.48 & 7.994 & 2.064 & .433 \\
\hline & & Female & 15 & 24.74 & 2.795 & .721 & .437 \\
\hline \multirow[t]{6}{*}{ Black } & \multirow[t]{2}{*}{ Height ${ }^{*}$} & Male & 15 & 49.85 & 2.682 & .692 & .013 \\
\hline & & Female & 15 & 46.57 & 3.931 & 1.015 & .013 \\
\hline & \multirow[t]{2}{*}{ Upper width* } & Male & 15 & 18.66 & 2.484 & .641 & .239 \\
\hline & & Female & 15 & 17.60 & 2.349 & .606 & .239 \\
\hline & \multirow[t]{2}{*}{ Lower width } & Male & 15 & 28.00 & 1.395 & .360 & .007 \\
\hline & & Female & 15 & 25.71 & 2.669 & .689 & .008 \\
\hline \multirow[t]{6}{*}{ Brown } & \multirow[t]{2}{*}{ Height ${ }^{*}$} & Male & 15 & 51.33 & 3.412 & .881 & .004 \\
\hline & & Female & 15 & 47.99 & 2.274 & .587 & .004 \\
\hline & \multirow[t]{2}{*}{ Upper width* } & Male & 15 & 17.40 & 1.998 & .516 & .378 \\
\hline & & Female & 15 & 16.70 & 2.294 & .592 & .378 \\
\hline & \multirow[t]{2}{*}{ Lower width ${ }^{*}$} & Male & 15 & 26.13 & 2.110 & .544 & .352 \\
\hline & & Female & 15 & 25.34 & 2.441 & .630 & .352 \\
\hline
\end{tabular}

\section{DISCUSSION}

The characteristics of the piriform aperture have been regarded as a classic indicator of sexual dimorphism. Differences in the width and height of the piriform aperture show higher values among males. Differences in the height of the piriform aperture were more significant among individuals who are white, black and brown. In the skulls of black individuals, significant differences were observed in the upper width of the piriform aperture.

In other populations, Hommerich \& Riegel's study on 116 German skulls, showed an average of $16.0 \mathrm{~mm}$ in males and $15.4 \mathrm{~mm}$ in females in the upper width of the piriform aperture. The mean of the lower width of the aperture was $23.6 \mathrm{~mm}$ in males and $22.6 \mathrm{~mm}$ in females, which are similar to those reported in our study, where we found values of $17.6 \mathrm{~mm}$ and $17.2 \mathrm{~mm}$ in male and female skulls, respectively. The lower width showed more distant values with $26.8 \mathrm{~mm}$ in males and $25.2 \mathrm{~mm}$ in females.

Lang \& Baumeister reported similar results for the German population, where the mean upper width of the piriform aperture was $16.3 \mathrm{~mm}$, with measured values of $22.0 \mathrm{~mm}$ maximum and $10.0 \mathrm{~mm}$ minimum in their sample. The lower width had a mean value of $23.6 \mathrm{~mm}$, a maximum of $28 \mathrm{~mm}$ and minimum of $20 \mathrm{~mm}$, without distinction by sex.

A study by Hwang et al., on the Korean population 
determined that the size and shape of nasal bones and piriform aperture can be used to identify the anthropological characteristics of each population. The height of the piriform aperture was reported in male individuals to be $30.1 \pm 2.6$ $\mathrm{mm}$ and in females to be $28.0 \pm 2.8 \mathrm{~mm}$. The upper width of the piriform aperture was $16.8 \pm 2.6 \mathrm{~mm}$ in males and $17.0 \pm$ $2.0 \mathrm{~mm}$ in females. The lower width of the piriform aperture was $25.7 \pm 1.7 \mathrm{~mm}$ and $25.4 \pm 2.1 \mathrm{~mm}$ for males and females, respectively. Their data of the upper and lower width were similar to that found in the skulls of our Brazilian sample. The height was quite dissimilar, where the Brazilians have a piriform height well above the Koreans. Erdem et al. (2004) studied 80 adult Turk skulls, which showed an average size in the lower width of the piriform aperture of $21.6+/-2.2$ mm (range: 17-27 mm), $21.9+/-2.1 \mathrm{~mm}$ (range: 18-27 $\mathrm{mm}$ ) in males and $21+/-2.2 \mathrm{~mm}$ (range: 17-26 mm) in female. These values are lower than the results of our study in both sexes. Lee et al. made measurements on the piriform aperture by three-dimensional computerized tomography in 75 Korean patients (17 females and 58 males). They determined the width of the piriform aperture in male skulls to be $24.34( \pm 2.33) \mathrm{mm}$ and $22.82( \pm 2.04) \mathrm{mm}$ in female skulls, with significant differences in both sexes.

Hoffman et al. found that the average value in the lower width of the piriform aperture in white individuals was $23.7 \mathrm{~mm}$, significantly lower than in black individuals, with an average of $26.7 \mathrm{~mm}$. Our results also show greater values for blacks in the lower width of the piriform aperture. Similar measurements showed that skulls of brown and white individuals also have lower values than blacks.

Ofodile did a study of 20 skulls, where 6 skulls were from the Ashanti tribe in West Africa, 5 were black American skulls, 5 were skulls from Austria in northern Europe, and 4 were American Indian skulls. On average, the width of the piriform aperture was $21.6 \mathrm{~mm}(17-24 \mathrm{~mm})$. Moreover, the piriform aperture in the Ashanti was oval, while in Austrians and American Indian the aperture was a triangular shape. In Black Americans, the piriform aperture varied from triangular to oval, showing differences in different population groups. Prescher et al. (2005) anthropologically assessed 184 human skulls, and described the piriform aperture in males to have a higher and larger area. In females, the piriform aperture is relatively wide in caudal, but becomes reduced cranially. The piriform aperture in both cases had a pear shape, where the two seem quite similar but not identical.

Anthropological studies suggest that climatic influences may affect the width or breadth and height of the piriform aperture (Wolpoff, 1968). The piriform aperture directly affects the heating and humidity of the inspired air. In cold and dry climates, the heating and humidification of inhaled air is facilitated by a longer nasal passage and a narrower piriform aperture (which reduces the base of the nose), due to increased surface and longer period during which the air is inspired (Ofodile; Lee et al.). For this reason, it is speculated that the shape of the piriform aperture is adapted to the environment in a way that reflects geographical variations (Hwang \& Kang, 2003). However, sometimes a close piriform aperture can be found as a congenital anatomic variation (Hommerich \& Riegel). Reported findings indicate that the piriform aperture continues to develop even after 20 years of age. The width of the piriform aperture increases twice from childhood to adulthood (Lang \& Baumeister).

According to the sexual dimorphism of the piriform aperture, males exhibit larger piriform aperture sizes and height (Rosas \& Bastir, 2002). As a parameter in classic sexual dimorphism in complete or partial skeletons, it is very important to have specific population values (Suazo et al., 2008b), because the skeletal features vary in different populations.

CANTín, L. M.; SUAZO, G. I. C; ZAVANDO, M. D. A \& SMITH, R. L. Determinación de dimorfismo sexual mediante análisis morfométrico de la apertura piriforme en cráneos humanos Brasileños. Int. J. Morphol., 27(2):327-331, 2009.

RESUMEN: El diagnóstico del sexo a partir de osamentas humanas es importante en investigación antropológica y forense, éste puede ser realizado mediante análisis cualitativos o cuantitativos de parámetros morfológicos de dimorfismo. La forma de la apertura piriforme es uno de los indicadores clásicos de dimorfismo sexual, a partir de ella se han descrito diferencias entre hombres y mujeres en sus dimensiones, con un fuerte comportamiento población-específico. El propósito de este estudio fue analizar la presencia de dimorfismo sexual en las dimensiones de la apertura piriforme y su relación con el color de piel de los individuos. Se utilizaron 90 cráneos humanos de la Colección de la Universidade Federal de São Paulo (UNIFESP), con registro de sexo, edad y color de piel (clasificadas en blanco, negro y pardo). Las dimensiones analizadas fueron: altura, ancho superior e inferior de la apertura piriforme. Todas las dimensiones resultaron mayores en hombres que en mujeres, sin embargo, sólo la altura de la apertura piriforme resultó ser significativa con $\mathrm{p}<0.01$. Al analizar las diferencias agrupándolas por color de piel, obtuvimos que la altura de la apertura piriforme resultó ser mayor y significativa ( $<<0.05$ ) en hombres blancos, negros y pardos. En el grupo de cráneos de individuos negros, además, encontramos diferencias significativas en el ancho superior $(\mathrm{p}<0.05)$. Las principales diferencias encontradas, referidas a la altura de la apertura piriforme, y la baja influencia del color de piel en la presencia de dimorfismo sexual en las dimensiones de la apertura piriforme, contrastan con lo reportado en la literatura y justifican la revisión de los indicadores clásicos utilizados para el diagnóstico del sexo en poblaciones específicas.

PALABRAS CLAVE: Dimorfismo sexual; Apertura piriforme; Cráneos. 
CANTíN, L. M.; SUAZO, G. I. C; ZAVANDO, M. D. A \& SMITH, R. L. Sexual dimorphism determination by piriform aperture morphometric analysis in Brazilian human skulls. Int. J. Morphol., 27(2):327-331, 2009.

\section{REFERENCES}

Correia, H.; Balseiro, S. \& De Areia, M. Sexual dimorphism in the human pelvis: testing a new hypothesis. Homo, 56(2):153-60, 2005.

Erdem, T.; Ozturan, O.; Erdem, G.; Akarcay, M. \& Miman, M. C. Nasal pyriform aperture stenosis in adults. Am. J. Rhinol., 18(1):57-62, 2004.

Hoffman, B.E.; McConathy, D. A.; Coward, M. \& Saddler, L. Relationship between the piriform aperture and interalar nasal widths in adult males. J. Forensic Sci., 36:1152-61, 1991.

Hommerich, C.P. \& Riegel, A. Measuring of the piriform aperture in humans with 3D-SSD-CT-Reconstructions. Ann. Anat., 184:455-9, 2002.

Hwang, T. S. \& Kang, H. S. Morphometry of nasal bases and nostrils in Koreans. Ann. Anat., 185:189-93, 2003.

Hwang, T. S.; Song, J.; Yoon, H., Cho, B. P. \& Kang, H. S. Morphometry of the nasal bones and piriform apertures in Koreans. Ann. Anat., 187(4):411-4, 2005.

Krogman, W. M. \& Iscan, M. Y. The Human Skeleton. In Forensic Medicine. Springfield, lllinois, Charles C. Thomas Pub., 1986.

Lang, J. \& Baumeister, R Uber das postnatale Wachstum der Nasenhohle. Gegenbaurs Morphol., 128:354-393, 1982.

Lee, S. H.; Yang, T. Y.; Han, G. S.; Kim, Y. H. \& Jang, T. Y. Analysis of the nasal bone and nasal pyramid by threedimensional computed tomography. Eur. Arch. Otorhinolaryngol., 265(4):421-4, 2008.

Ofodile, F. A. Nasal bones and pyriform apertures in blacks. Ann. Plast. Surg., 32(1):21-6, 1994.

Pascalis, O.; de Haan, M. \& Nelson, C. A. Is face processing species-specific during the first year of life? Science, 296(5571):1321-3, 2002.

Prescher, A.; Meyers, A. \& Gerf von Keyserlingk, D. Neural net applied to anthropological material: A methodical study on the human nasal skeleton. Ann. Anat., 187(3):261-9, 2005.
Rogers, T. L. Determining the sex of human remains through cranial morphology. J Forensic. Sci., 50(3):493-500, 2005.

Rosas, A. \& Bastir, M. Thin-plate spline analysis of allometry and sexual dimorphism in the human craniofacial complex. Am. J. Phys. Anthropol., 117(3):236-45, 2002.

Suazo, G. I. C. ; Zavando, M. D. A. \& Smith, R. L . Accuracy of palate shape as sex indicator in human skull with maxillary teeth loss. Int. J. Morphol., 26(4):989-93, 2008a.

Suazo, G. I. C. ; Zavando, M. D. A. \& Smith, R. L . Blind test of mandibular morphology with sex indicator in subadult mandibles. Int. J. Morphol., 26(4):845-8, 2008b.

Suazo, G. I. C. ; Zavando, M. D. A. \& Smith, R. L . Sex determination using mastoid process measurements in Brazilian skulls. Int. J. Morphol., 26(4):941-4, 2008 c.

Williams, B. A. \& Rogers, T. Evaluating the accuracy and precision of cranial morphological traits for sex determination. J. Forensic Sci., 51(4):729-35, 2006.

Wolpoff, M. H. Climatic influence on the skeletal nasal aperture. Am. J. Phys. Anthropol., 29:405-23, 1968.

\section{Correspondence to: \\ Dr. Mario Cantín \\ Department of Normal Anatomy \\ Universidad de Talca \\ Avenida Lircay s/n Oficina No104 \\ Talca - CHILE \\ Phone: 56-71-201682}

Email: mcantin@utalca.cl

Recibido : 22-01-2009

Aceptado: 18-02-2009 
